\title{
Economic Valuation of Ecosystem Services: a Case Study for Sustainable Management of Degraded Peatlands in Latvia
}

\author{
Dr.oec. Elina Konstantinova \\ Ventspils University College \\ Ventpils, Latvia \\ elina.konstantinova@gmail.com \\ Dr.oec. Anda Zvaigzne \\ Research Institute for Business \\ and Social Processes, Faculty of \\ Economics and Management \\ Rezekne Academy of Technologies \\ Rezekne, Latvia \\ anda.zvaigzne@rta.lv
}

\author{
Dr. oec. Liga Brunina \\ Association "Baltic Coasts" \\ Riga, Latvia \\ liga.brunina@gmail.com
}

\author{
Dr.paed. Aija Persevica \\ Association "Baltic Coasts" \\ Riga, Latvia \\ aija.persevica@gmail.com
}

\begin{abstract}
Ecosystem services (ES) are the benefits that people obtain from using ecosystems and can be divided into the following three categories: provisioning, regulating and supporting and cultural services. The strategical importance of ecosystem services is set by the EU Biodiversity Strategy, which put ecosystem services firmly on the EU policy agenda. The aim of the paper is to present and discuss the model for economic (monetary) valuation of ecosystem services for sustainable management of degraded peatlands in Latvia.

Based on an economic valuation of ecosystem services (ES), it is possible to compare different territories and different management scenarios. Peatland ecosystems globally represent a major store of soil carbon, a sink for carbon dioxide and a source of atmospheric methane. Climate change may threaten these stocks due to the peat oxidation caused by the draught in areas where the peat extraction has been carried out, as well as the increased risk of forest fires. In Latvia, currently there have not been developed a strategy for the implementation of standard approaches and basic principles for the management of degraded peatlands. There are several options for re-cultivation of degraded peatlands, but for sustainable land use, it is very important to choose the most optimal option from the economic, ecological and society perspective.
\end{abstract}

The research was based on data obtained from a biophysical ES assessment for 28 indicators for 3 scenarios from a 5, 25 and 50-year perspective. The collection of primary data, as well as an aggregation and comparative assessment of secondary data have been carried out by using approbated scientific research methods and ES assessment indicators. The obtained data were adapted to the Latvian socio-economic situation by using correction factors. Depending on ES category, the following assessment methods were used: the market pricing method; the benefit transfer method and the direct market pricing method; the avoided costs method.

Economic valuation of peatland re-cultivation scenarios assists land-use planners and policymakers in making ecologically, economically and socio-culturally sustainable land-use decisions, where ecological and economic data are used for a calculated assessment of the land-use options.

Keywords - Ecosystem services, Economic valuation, degraded peatlands, Land use planning, Sustainable management

\section{INTRODUCTION}

The United Nations Initiative Millennium Ecosystem Assessment, which was started in the year 2000 , defines ecosystem services as "the benefits people obtain from ecosystems" [1].

The assessment of ecosystem services has a significant role in the member States of the European Union (EU), reflected in the EU Biodiversity Strategy until 2020, which requires the Member States to map and assess the condition of the ecosystems and their services, as well as to assess the economic value of these services until 2020 and to promote the inclusion of economic values into the systems of reporting and accounting [2].

Ecosystem services (ES), in general, are divided into three major categories:

- Provisioning services - direct gains of materials and resources, which people obtain from ecosystems (food, drinking water etc.);

- Regulating services - the services that ecosystems provide by acting as regulators e.g. regulating the quality of air and soil or by providing flood and disease control;

- Cultural services - non-material benefits from ecosystem services, which influence the psychological and mental state of persons (active/passive recreation, environmental education etc. [3].

Economic valuation of ecosystems and their services is necessary in order to assess the anthropogenic impact on the ecosystems; by using the values, ecosystems and their services provide:

- Economic valuation methods of ES allow demonstrating the indirect values of the ecosystem 
services, which are difficult to assess for society, but in the monetary form the values are demonstrated;

- ES economic valuation helps with the decisionmaking when two or more development scenarios have to be compared. When expressing the values in uniform monetary units, the scenarios can be compared.

Peatlands belong to most threatened nature types in Europe. The global importance of peatlands for carbon storage and climate change mitigation has only recently been recognised in international policy - only since 2008 organic soils have been a subject of discussion. While peatlands represent only $2 \%$ of cultivated land in the $\mathrm{EU}$, they are responsible for more than $50 \%$ of the $\mathrm{CO} 2$ emissions of this sector [4].

Moreover, peatland ecosystems are globally valuable in terms of biodiversity, as well as economic importance of the areas varies with respect to the potential options of economic activities to be carried out within. The sustainable management of degraded peatlands has a particular potential to make an important contribution to climate change mitigation and both economic and environmental benefits to society.

\section{MATERIALS AND METHODS}

When assessing the ecosystem services, a concept of economic values has to be taken into account, which involves Total Economic Value (TEV). TEV consists of direct and indirect values, and the non-use values, see Fig. 1.

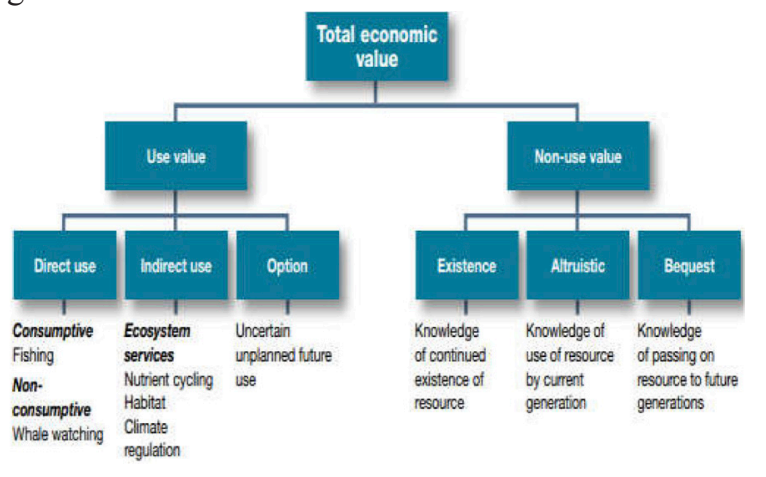

Source: authors'study

Fig. 1 Total Economic Value for ES economic assessment.

An economic valuation was performed for five demo sites (degraded peatlands and their adjacent territories in Latvia) in the current situation and for three development (management) scenarios (for 5-, 25- and 50- year periods). The demo sites and scenarios are:

1) Kaigu mire $\rightarrow$ Blueberry plantations;

2) Kaigu mire $\rightarrow$ Energy wood plantations;

3) Lielais Kemeru Tīrelis mire $\rightarrow$ Sphagnum (peat moss) plantations

4) Kaudzǐšu mire $\rightarrow$ Cranberry plantations

5) Laugas mire $\rightarrow$ Re-naturalisation of the territory.

To assess the monetary value of ES, different methods are used: the direct pricing/market price method; the production function method; the avoided cost method, the replacement cost method; the contingent valuation method; the travel cost method; the hedonic pricing method; the benefit transfer method; other methods or their combination [5]. The authors performed an economic valuation by secondary data collection and comparative assessments, using the methods described in scientific research, and the indicators already prepared by ecosystem service experts prior to the economic evaluation. When assessing economic values of ES, the monetary value of the ecosystem service in a given territory (area) is expressed in comparative units (money units/ha/year, or EUR/ha/year).

Depending on the category (group) of ecosystem services, the following methods were used:

- Provisioning services - the market price method and the production function method;

- Regulating services - the avoided cost method, the benefit transfer and cost replacement method;

- Cultural services - the market price method; the benefit transfer method; the contingent valuation method and the travel cost method [6].

The results of the economic assessment of ES of the Project demo sites were adjusted to the Latvian socioeconomic situation.

\section{RESULTS AND DISCUSSION}

\section{Monetary values and findings for the current situation}

The authors have calculated the Total Economic Value (TEV) for each of the demo sites in the current situation. When summarising the findings of the monetary valuation, the highest economic value (EUR/ha/year) was found for the Kaigu mire demo site (where energy wood plantation is planned), followed by the Laugas mire and Kaigu mire blueberry plantation demo sites (Fig. 2).

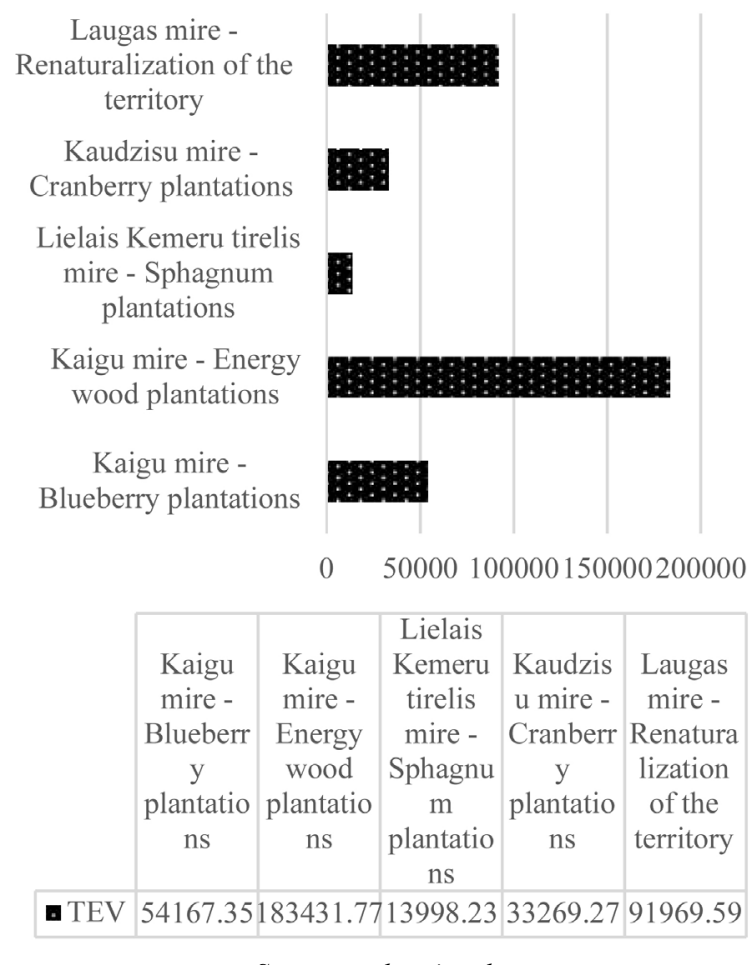

Source: authors'study

Fig. 2 Total economic value for the demo sites, EUR/ha/year. 
When analysing by ES group, each of the demo sites demonstrates its own specifics. For example, it can be dominated by provisioning services (Kaigu mire energy wood plantation demo site $-95 \%$ ) or regulating (as the Lielais Ķemeru Tīrelis mire Sphagnum plantation demo site - 99\%). In the Kaigu mire energy wood plantation demo site, for example, a large proportion of provisioning services relates to peat production in the area of 250 ha, while in the other demo sites the peat production areas are smaller (e.g. Laugas mire, 132.75 ha) or there is no peat production at all (Kaigu mire blueberry plantation demo site, Lielais Kemeru Tīrelis mire Sphagnum plantation site and the Kaudzī̌su mire cranberry plantation demo site).

In all the demo sites, cultural services have the lowest value, proportionally being close to zero value.

\section{Monetary values and findings for development sce- narios}

Economic values for the development scenarios were simulated for the following perspectives:

- Laugas mire - the re-naturalisation area scenario, for 25 and 50 years (providing that the situation will not change after 5 years);

- Kaigu mire blueberry, energy wood, Lielais Kemeru Tīrelis mire Sphagnum plantations and Kaudzīšu mire cranberry plantation for 5-, 25- and 50-year periods.

The methodology was the same as that used for assessment of the current situation.

Monetary values were changed in accordance with the changes in the indicators of biophysical evaluation of ES.

Fig. 3 shows the economic values for provisioning ES for the development scenarios in all the demo sites. The values of provisioning ES services for a 5- year period are similar for all the demo sites. The lowest value for a 5-year period is for the Kaigu mire energy wood plantation scenario, which can be explained by the fact that wood is not harvested in a so short time period.

The highest provisioning ES value for a 25 - and 50year period is for the Kaigu mire blueberry plantation scenario due to the highest productivity in every 25 years. Provisioning services for the Kaudzīšu mire cranberry plantation scenario remain the same for a 5-, 25- and 50year period. It relates to the need to restore the cranberry plantations after a certain period of time.

A comparatively high value of provision services is also for Laugas mire re-naturalised territory, mainly due to harvesting potential of wild berries and remedial herbs and Sphagnum donor material.

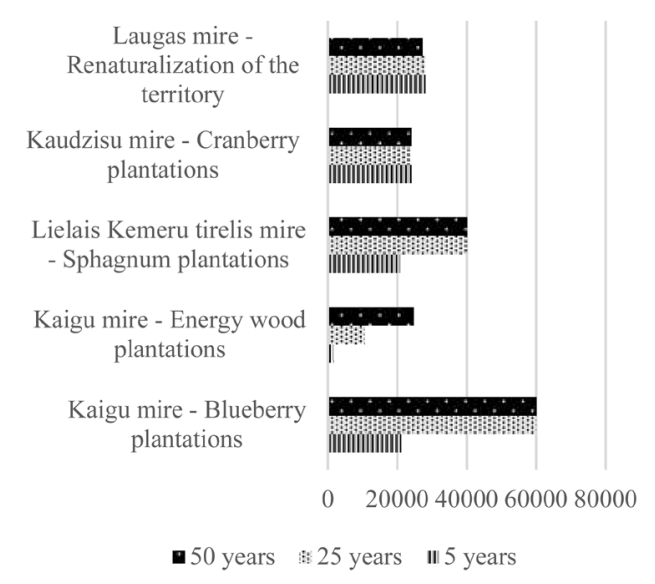

Source: authors'study

Fig.3 Economic values of provisioning ES for the development scenarios for all the demo sites, EUR/ha

By evaluating the demo sites and development scenarios regarding their ability to provide ecosystem regulating services, it can be concluded that there are very minimal changes in a 5-, 25- and 50-year period (Fig. 4).

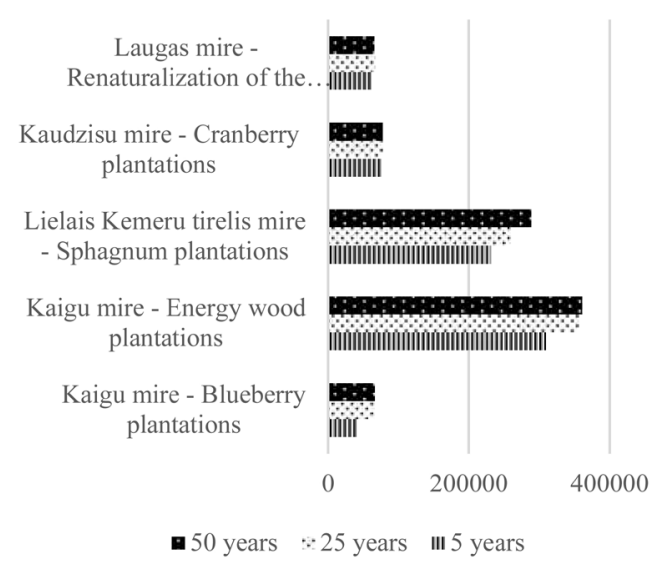

Fig.4 Economic values of Regulating ES for development scenarios for all demo sites EUR/ha

The highest regulating ES value is for the Kaigu mire energy wood plantation scenario, which mainly relates to the potential of reduction of adverse effects of climate change and micro climate regulation. A relatively high value of provisioning services is also for the Lielais Ķemeru Tīrelis mire Sphagnum (peat moss) plantation scenario. It relates to the fact that natural mire territory has high potential for filtration, sequestration, storage and accumulation of soil and water and wide biodiversity.

The lowest economic value of regulating services is for the Kaigu mire blueberry plantation demo site, especially for a 5-year period. It relates, firstly, to the fact that blueberry plants are too small to provide regulation services and, second, to the fact that blueberry cultivation should use a wide spectrum of fertilisers that decreases the value of the regulating services.

The values of cultural services in the demo sites are significantly lower than the economic values of the other ecosystem services groups (Fig. 5). 


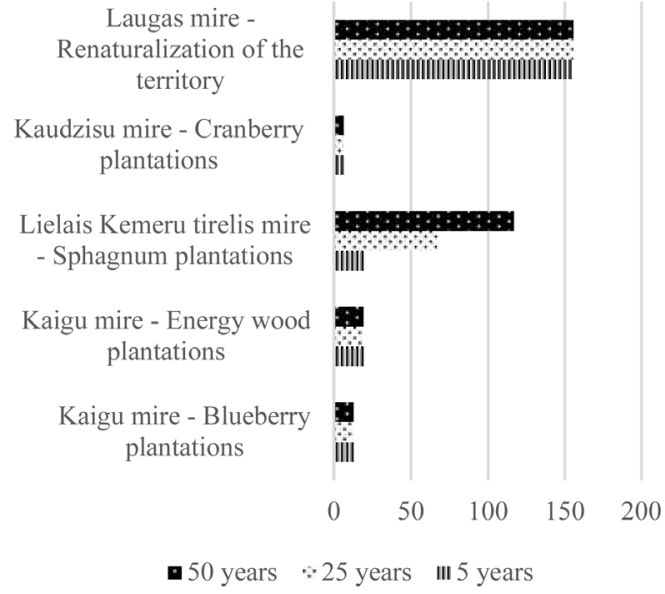

Source: authors'study

Fig.5 Economic values of cultural ES for the development scenarios for all the demo sites, EUR/ha

In addition, the economic values of cultural services are almost identical for all the development scenarios (for 5-, 25- and 50-year periods) for all the demo sites. An exception is the Lielais Kemeru Tīrelis mire Sphagnum plantation demo site, where the value of cultural services significantly increases in a 25 - and 50 -year period. This can be explained by the fact that natural mire territory provides more possibilities for active and passive (recreation) and environmental education than degraded peatlands.

In general, the highest economic value of cultural services is for the Laugas mire re-naturalised demo site, because this territory can provide high potential of cultural services such as bird watching, active and passive recreation and environmental education.

\section{CONCLUSIONS}

Analysing the current situation within the demo sites in respect to their ability to provide ES, it can be concluded that existing peat extraction fields provide high economic values of provision services; on the other hand, they provide very low values for regulation and cultural services. The natural mire territories provide high values of regulation services and comparatively higher values of cultural services. The ES economic values of degraded peatlands are low in all the ES groups. This conclusion shows necessity for sustainable management measures for increasing the provision of ES from degraded peatlands.

Analysing the development or management scenarios for degraded peatlands, it can be concluded that a common feature is that the Sphagnum (peat moss) plantations in 5-, 25- and 50-year periods provide the highest economic values of ES. From the economic activity perspective, the highest economic value is for blueberry plantations and energy wood plantations. From the cultural services perspective, the highest economic value is for renaturalised territory.

The economic assessment of ES allows comparing different land use management scenarios from different perspectives - their ability to provide supply of products and materials, ability to regulate viability of the ecosystem and climate and ability to provide cultural services.

Economic assessment of ES is an important support tool for decision-making on different land use scenarios, but at the same it is important also to assess the financial return from each of the scenarios.

\section{ACKNOWLEDGEMENTS}

The research underlying this manuscript has been conducted within the "LIFE REstore - Sustainable and responsible management and re-use of degraded peatlands in Latvia" (LIFE14 CCM/LV/001103) project, co-financed by the European Union.

\section{REFERENCES}

[1] MA (Millennium Ecosystem Assessment). Ecosystems and Human Well-being: Synthesis. 2005, Island Press, Washington, D.C.

[2] European Commission. Our life insurance, our natural capital: An EU biodiversity strategy to 2020. COM, 2011, Brussels.

[3] Common International Classification of Ecosystem Services, Version 4.1., European Environment Agency, https://cices.eu

[4] Opinion of the Committee of the Regions on "Implementation of the Soil Thematic Strategy" (2013/C 17/08) Official Journal European Union 17, 19.1.2013, p. 37-44

[5] R. de Groot, L. Brander, S. van der Ploeg, R. Costanza, Fl. Bernard, L. Braat, M. Christie, N. Crossman, A. Ghermandi, L. Hein, S. Hussain, P. Kumar, A. McVittie, R. Portela, L. C. Rodriguez, P. ten Brink, P. van Beukering (2012). Global estimates of the value of ecosystems and their services in monetary units. Ecosystem Services 1, pp. 50-61.

[6] U. Pascual, R. Muradian, L. Brander, E. Gomez-Baggethun, B. Martin-Lopez, M. Verma, P. Armsworth, M. Chritie, H. Cornelissen, F. Eppink, J. Farley, J. Loomis, L. Pearson, C. Perrings, S. Polasky. (2010). The economics of valuing ecosystem services and biodiversity. In: Kumar, P. (Ed.), TEEB Foundations, The Economics of Ecosystems and Biodiversity: Ecological and Economic Foundations. Earthscan, London (Chapter 5), 133 pp. http://www.teebweb. org/our-publications/teeb-study-reports/ecological-and-economic-foundations/ 